\title{
Antecedents and Consequences of E-Learning Adoption in Jordanian Higher Education Institution
}

\author{
Dr. Manal A. Altawalbeh \\ Faculty of Educational Sciences \\ Middle East University, Amman, Jordan \\ Dr. Hamzeh Alassaf \\ Faculty of Educational Sciences \\ Middle East University, Amman, Jordan
}

\begin{abstract}
This research aimed at investigating the factors influencing instructor's intention to adopt e-learning by usingTechnology Acceptance Model in Jordanian universities. The paper takes a social and technical approach in its investigation by using a research theory based on Technology Acceptance Model (TAM) to identify the factors that affect intention to adopt e-learning. The sample consisted of (320) instructors. They were drawn randomly from the population, by using proportional stratified random sample method. A questionnaire was develop to collect data. Validity and reliability of the tool were assured. Multiple regression Analysis was used to assess the relationships in the constructs. The findings indicated that the perceived usefulness (PU) has a significant influence on behavioral intention (BI) $(P<0.01)$, perceived usefulness (PU) and perceived ease of use (PEOU) have significant influence on Attitude (AT) $(P<0.01)$,but attitude $(A T)$ has no significant impact on behavioral intention $B I(P>0.01)$.The study also provides an indicator of instructors' acceptance of e-learning as well as identifying the important factors that would contribute to its successful use. The outcomes will enrich the understanding of instructor's acceptance of e-learning and will assist in its continuing implementation at Jordanian Universities.
\end{abstract}

Keywords: Attitude, Behavioural intentions, E-learning,Perceived usefulness, Perceived ease of use, TAM.

\section{INTRODUCTION}

Over the past decade there has been a huge revolution in learning and educational computer applications and the use of computers in education, is still in its first steps that increases day by day, but started to take several forms, from computer education to the use of the internet in education, and finally the concept of e-learning technical based to provide educational content to the learner in a good and effective way, through sophisticated computer systems designed for this purpose (Al-Mobaideen, Allahawiah, \&Alkhawaldeh, 2012; Muheisen, 2010; Qteishat et al., 2013).

Masrom (2007, p.1) defines e-learning as "learning facilitated and supported through the utilization of information and communication technology (ICTs)". Its use in different educational processes is designed to improve the performance of learning (AlAdwan\&Smedley, 2013). It may be used in many forms, i.e. as a supplement to traditional lectures, asynchronous distance learning, learning management systems or online learning (AlAdwan\&Smedley, 2013). The combination of traditional learning (face-to-face lectures) 
According to Yongmei, Elizabeth, and Habte (2012), e-learning has developed rapidly, supported by increasing sophistication in information technology and a better understanding of how to make content and delivery of e-courses effective in universities. Furthermore, elearning has been adopted by most countries around the world, and implemented by worldclass universities (Al-Adwan, AlAdwan, \&Smedley, 2013).

The quick growth of internet technologies and web based environments, e-learning is considered vital to all Arab countries. It is a solution to many of its human development problems, but on the other hand, this solution is not as smooth as it seems to be (Altarawneh, 2011). E-learning was rated the fastest growing industry in the field of educational resource production (Algahtani, 2014; Qteishat et al., 2013). Therefore, e-learning is facing a lot of obstacles, barriers, and challenges in Arab countries in its application and Jordan is not exception (Altarawneh, 2011; Qteishat et al., 2013). There is no doubt that the future of elearning in the field of education is certainly bright to all Arab countries (Subhash, 2012).

Several scholars have highlighted that, understanding the factors that influence users adoption and use of e-learning, is important for a better implementation and adoption of e-learning (Qteishat et al., 2013). Nonetheless, the lack of theoretical or conceptual framework in many past studies dealing with the adoption of e-learning, resulted in inconsistent results and left the question of what constitutes the determining factors of the adoption of e-learning (Al-Obisat et al., 2013). Consequently, demand for the development of e-learning is increasingly growing still need for research on potential factors affecting e-learning in all countries (Khasawneh, 2015), especially in Jordanian universities context (Al-Mobaideen, Allahawiah, \&alkhawaldeh, 2013; Khasawneh, 2015).

Although wide-ranging research has been carried out on implementation issues pertinent to elearning design, development, management, delivery, evaluation and operations (AdewoleOdeshi, 2014; Al-Shboul, 2013) instructors is primary considerations in adoption e-learning, and they play a crucial role in specifying the effectivity, success or inefficacy of adoption elearning (Ali Alamin\&Elgabar, 2014; McGill, Klobas, \&Renzi, 2014). Nevertheless, very little empirical research has been conducted on instructor adoption e-learning from the perspectives of user intention (Al-Shboul, 2013; Almarabeh, 2014; Nisperos, 2014). Therefore, it is critical to identify the factors that influence instructors adoption e-learning systems to help policymakers in higher education facilitate their use. So there has been and will be a necessity for educational institutions to examine instructors behavioral intention to adoption e-learning and need for research on potential factors affecting e-learning adoption (Ali Alamin\&Elgabar, 2014; Nisperos, 2014).

In this paper, the theoretical framework of university instructor's e-learning acceptance and intention to use technology is based on the technology acceptance model (TAM). TAM is robustto investigate the acceptance of various information system applications (Chen \& $\mathrm{Li}$, 2011). The model captures both practical and psychological implications in regards of the acceptance of a new information system. It considers the impact of perceived ease of use andperceived usefulness on instructors intention and attitude to use e-learning in their education.

\section{THEORETICAL FRAMEWORK}

Technology Acceptance Model (TAM) is an adaptation of the TRA to the field of information system which aims to accurately model how users respond to the presentation of a new technology, addressing factors such as their initial perception, level of acceptance and use of the technology. Davis (1989, cited in Masrom, 2007) first proposed the TAM to trace the 
impact of external variables on internal beliefs, attitudes and intentions to accept and use a computer-based technology.

According to TAM as can be perceived through Figure 1.2, user acceptance of any technology is measured by a person's behavioural intention to use the technology. Behavioural intention to use a system is determined by the user's attitude towards using the system and the belief of using the system would enhance his or her job performance (perceived usefulness). Attitude towards target system use is directly affected by two distinct constructs, perceived usefulness (PU) and perceived ease of use (PEOU). In addition, PEOU found to have a direct impact on PU. Behavioural intention directly affects actual system use. Actual system use is a behavioural response measured by the individual's actions in real life. Frequency of use and amount of time spent using a target system is typical of the usage metrics (Davis, 1993)

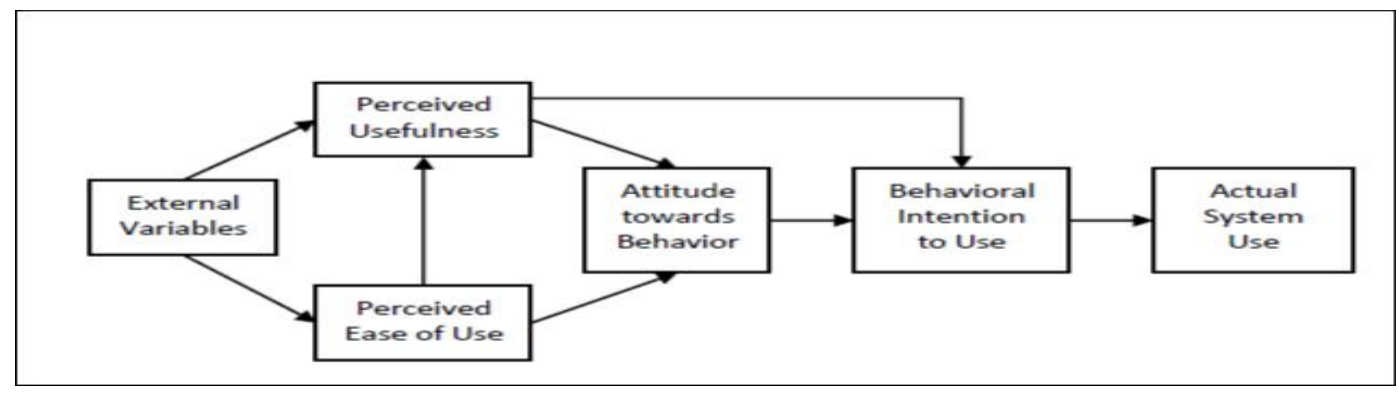

Figure 1: Technology Acceptance Model (adapted from Davis et al., 1989)

TAM appears particularly effectiveness due to its identification of two user acceptance constructs: PU and PEOU, which simplified previous theoretical attempts to measure attitudes towards technology. Thus, TAM has been applied as a reliable and robust model for predicting the user adoption of different technologies, includebut not limited to predicting e-commerce purchasing intention (Maditinos et al., 2007); investigating intention to use Decision Support System (DSS) within medium and large business organisations in Croatia (Dulcic,Pavlic\&Silic, 2012); predicting tablet computer use among residents or physicians in pediatrics or medicalpediatrics in the United States (Ducey, 2013).

\section{Behavioral Intention to Adopt E-learning}

Intention is a psychological construct that refers to an individual's motivation in the form of his or her conscious plan to exert effort to perform behavior (Ajzen, 2005). The concept of intention occupies a central position in cognitive approaches to understanding human behavior (Ajzen, 2012). The concept has been tackled in social psychology research since the early 1950's (Ajzen, 2005, 2012). Intention has commonly been viewed as the "conative" or behavioural component of the tripartite conception of attitude (Rosenberg \&Hovland, 1960). Therefore, measures of attitude and intention have often been applied interchangeably to serve as indicator of a person's attitude (Ajzen, 2005).

There is empirical evidence supporting the links between BI and attitudes. From a broader perspective, several meta-analyses of the literature on TRA, TPB and TAM offered a good support for these links (Abbasi et al., 2013; Qteishat, et al., 2014).

Ajzen's (2005) definition of attitude as a "disposition to respond favorably or unfavorably to an object, institution or event", represents this view. The latter approach conceives attitude as including three components: affective, cognitive and behavioural (Kruglanski\&Stroebe, 2005).

In TAM and TPB context, attitude is defined as the mediating affective response between usefulness and ease of use beliefs and intentions to use a target system (Suki\&Suki , 2011; 
Qteishat et al., 2014). These beliefs work as the fundamental source of determining the individual's attitudes. That is the basic building blocks of attitudes (Ajzen\&Fishbein, 1980). Davis (1989) stated that one's overall attitude toward using a given system is an antecedent to intentions to use. PU is defined as "the degree to which a person believes that using a particular system would enhance his or her job performance" (Davis, 1989). PU is similar to the construct of relative advantage suggested by Rogers in his PCI model (Moore \&Benbasat, 1991). A system that is useful in performing the required tasks will allow the user to achieve better performance and benefit from its use (Davis, 1989). Davis (1989) defined Perceived Ease of Use (PEOU) as "the degree to which a person believes that using a particular system would be free from effort" (Davis, 1989). PEOU represents an individual's intrinsic motivation to use a technology (Arbaugh, 2002). However, previous studies found that PU and PEOU are strong predictors of attitude to accept and use a technology (Qteishat et al., 2014).

\section{Defining the research hypotheses}

High level of perceived usefulness (PU) results in more positive attitude (AT) (Abbad et al., 2010; Teoet al, 2008).Perceived use (PU) has been consistently found as a direct determinant of behavioral intention (BI), and it also influences user's (BI) indirectly as a direct determinant of AT (Abbad et al., 2011; Liu et al.2005).Therefore,

H1: Perceived usefulness (PU) will significantly influence the intensity of instructorsbehavioral intention (BI).

H2: Perceived usefulness (PU) will significantly influence the intensity of instructorsAttitude(AT).

Perceived ease of usefulness(PEOU) was theorized as a direct determinant of attitude (AT) by many researchers (Abbad et al., 2011; Park, 2009; Chang ,Yan\& Tseng, 2012). Improvements in ease of use may not only be beneficial to influence intentions, but also lead to positive attitude. Additionally,PEOU was found to indirectly impact behavioral intention (BI) through increased perceived usefulness(PU) (Alatawi et al. 2014; Seket al., 2010; Lee,Hsieh\& Hsu., 2011). Teo (2009) argues that perceived usefulness (PU) mediates the effect of perceived ease of use (PEOU) on attitude (AT). Enhanced ease of use (EOU) produces better performance and greater perception of usefulness (Venkatesh and Davis, 2000). Therefore,

H3: Perceived ease of use (PEOU) will significantly influence the intensity of instructorsattitude (AT).

H4: Perceived ease of use (PEOU) will significantly influence perceived usefulness (PU).

Finally, according to Ajzen and Fishbein (2005), AT drives behaviour and refers to the way that individuals respond to or ignore an object. More importantly, any efforts exerted to heavily implement e-learning rely on the involvement of users attitude. For example, if lecturers believe that technology is insufficient to satisfy their own needs or their instructors, they will resist using it in the learning process (Alatawi et al., 2014). Thus, successful e-learning engagement requires users to possess a positive attitude towards it (Huang \&Liaw, 2005).Therefore,AT has beenhypothesized as a direct determinant of behavioral intention (BI) in the available literature (Alatawi et al., 2014).Therefore,

H5: Attitude (AT) will significantly influence behavioral intention (BI). 


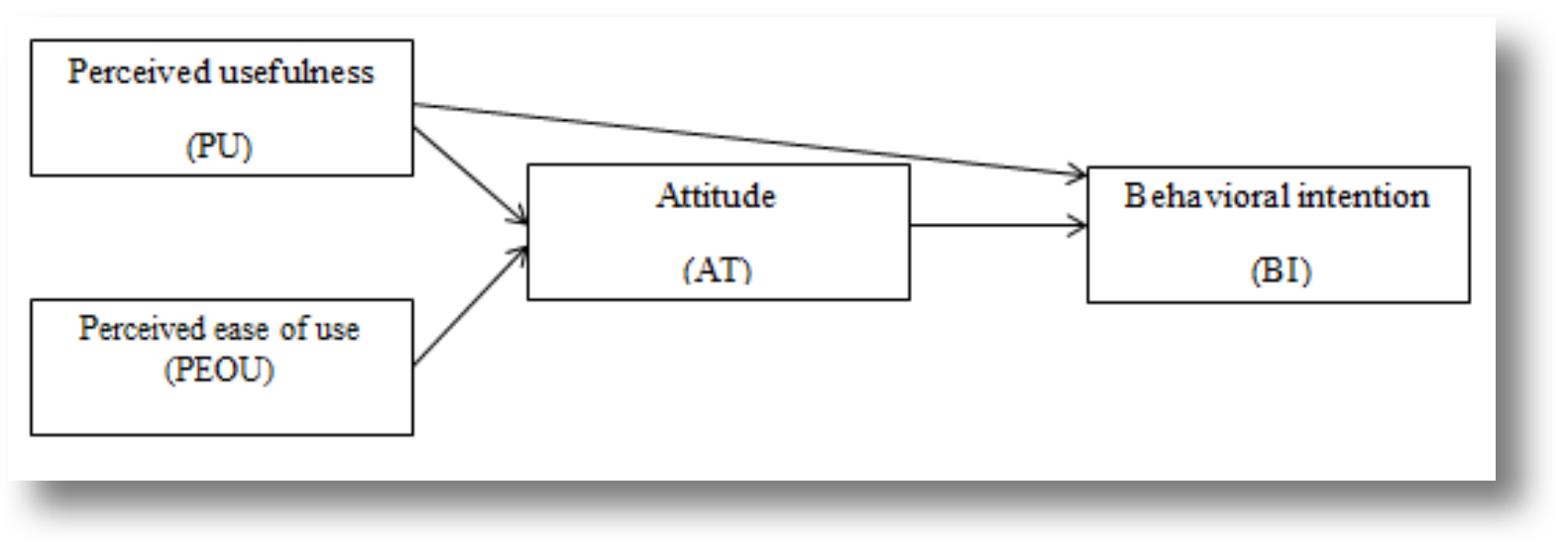

Figure2: Research Model Based on Original TAM (Davis et al., 1989)

\section{RESEARCH METHODOLOGY}

The researchers used the descriptive survey methodology, as the appropriate methodology for this research. The questionnaire was adopted to collect data.

\section{Research population}

The population of the research comprises of all instructors in both public and privet Jordanian universities. The population of this research was (4731) universities instructors holding different specialization.

\section{Research Sample}

The sample of study consists of instructorsof three public Universities and three private universities in Jordan who have introduced to e-learning. The sampling of this study is done in accordance with regional distributions in Jordan. Jordan is divided into three regions; northern, middle, and southern regions. Three public universities will be chosen randomly from all regions as follows: Yarmouk University from the northern region, Jordan University from the middle region, and Mu'tah University from the southern region. Similarly, three private universities will be chosen randomly as follows: Jerash University from the northern region, applied University from the middle region, and Al-Zaytoonah University from the southern region. The stratified random sampling method was used in sample selection. A total of 320 instructors from the six universities were drawn from the population by reference to Sekaran (2010) who determined sample size from the population.

\section{Research design}

Structured questionnaire was used in this research. Respondents were surveyed using fivepart questionnaire. Parts one concerns with the demographic data for instructors, the demographic data include: Gender, age, internet experience, Frequency of Internet, specialization, university and rank, part two measure elearning adoption intention, with six items adapted from Lee (2001).Part three measures attitude towards e-learning with five items taken from Ngai et al. (2007). Part four measures the perceived usefulness with seven items developed by Lee (2001) and Pituch and Lee (2006) while Perceived Ease of Use was measured in parts five with four items adapted from Lee (2001) and Pituch and Lee (2006). Questionnaire items were measured on a five point Likert-scale anchored at both extremes to 1 (strongly disagree) and 5 (strongly agree).

\section{Research variables}

Dependent variables:behavioral intention to adopt e-learning. 
Independent variables:

1. Attitude toward adopting e-learning

2. perceived usefulness

3. Perceived Ease of Use

\section{Statistical treatments}

The following statistical tools were used: Means, standard deviations, Cronbach-Alpha formula, and multiple regression.

\section{Measures}

The descriptive statistics of the four constructs are shown in Table 1 . The standard deviations range from .78 and .91 , and all means above midpoint of 2.00

Table 1: Descriptive Statistics

\begin{tabular}{|c|c|c|c|}
\hline Factors. & Question. & Mean & St.d dev. \\
\hline \multirow[t]{7}{*}{$\mathrm{BI}$} & BI1 & 3.0 & .80 \\
\hline & $\mathrm{BI} 2$ & 3.2 & .82 \\
\hline & BI3 & 3.1 & .80 \\
\hline & BI4 & 3.4 & .83 \\
\hline & BI5 & 3.3 & .81 \\
\hline & BI6 & 3.2 & .82 \\
\hline & Total & 3.2 & .81 \\
\hline \multirow[t]{6}{*}{ AT } & AT1 & 3.31 & .81 \\
\hline & AT2 & 3.21 & .83 \\
\hline & AT3 & 3.40 & .85 \\
\hline & AT4 & 3.12 & .82 \\
\hline & AT5 & 3.50 & .88 \\
\hline & Total & 3.31 & .84 \\
\hline \multirow[t]{8}{*}{ PU } & PU1 & 3.1 & .80 \\
\hline & PU2 & 3.2 & .91 \\
\hline & PU3 & 3.1 & .87 \\
\hline & PU4 & 3.0 & .89 \\
\hline & PU5 & 3.3 & .87 \\
\hline & PU6 & 3.2 & .88 \\
\hline & PU7 & 3.3 & .89 \\
\hline & Total & 3.18 & .87 \\
\hline \multirow[t]{5}{*}{ PEOU } & PEOU1 & 3.01 & .84 \\
\hline & PEOU2 & 3.21 & .78 \\
\hline & PEOU3 & 3.32 & .83 \\
\hline & PEOU4 & 3.21 & .80 \\
\hline & Total & 3.19 & 0.81 \\
\hline
\end{tabular}

Construct validity and reliability have been tested to ensure that the results are reliable and consistent. The reliability analysis measured the internal validity and consistency of items used for each construct. Calculating Cronbach's alpha coefficient tested the factor reliability. This measures the internal consistency by indicating how a set of items are closely related as a group (Moola\&Bisschoff, 2012). Nunnally (1978) suggests that a Cronbach alpha value of 0.7 is acceptable, with a slightly lower value might sometimes be acceptable. Cronbach's alpha values for all factors are above 0.7 (see Table 2) indicating that all measures employed in this study demonstrate a satisfactory internal consistency. Therefore, the survey is considered a reliable measurement instrument. 
Table 2: Cronbach's Alpha

\begin{tabular}{|c|c|}
\hline Scale & Cronbach's alpha \\
\hline BI & .88 \\
\hline AT & .89 \\
\hline PU & .85 \\
\hline PEOU & .83 \\
\hline Total & .86 \\
\hline
\end{tabular}

\section{Analysis}

The hypotheses are tested by the Statistical Package for Social Sciences (SPSS) software. The total number of valid surveys is 238 , giving a response rate of around $74.3 \%$.

A regression analysis was conducted to test the first Hypothesis (H1), perceived usefulness (PU) as an independent variable and behavioral intention (BI) as dependent variable. Table 3 below summarizes the result of regression used to test $\mathrm{H} 1$.

Table 3: Regression results for $\mathrm{H1}$

\begin{tabular}{|l|l|l|l|l|l|}
\hline & $\beta$ & Standard Error of $\beta$ & $\mathrm{t}$ & $\mathrm{P}$ & $\mathrm{R}^{2}$ \\
\hline PU & 0.305 & 0.044 & 5.033 & $<0.01$ & 0.235 \\
\hline
\end{tabular}

As seen, perceived usefulness (PU) has significantly influenced behavioral intention (BI) $(P<0.01)$.

Therefore, AT dramatically impacts on BI. Consequently, hypothesis 1 (H1) is supported.

Regarding Hypothesis 2 (H2), the regression analysis shows that perceived usefulness (PU) significantly influences and Attitude (AT) $(P<0.01)$. The results presented in Table 4 indicate that PU significantly influences AT

Table 4: Regression results for $\mathrm{H} 2$

\begin{tabular}{|l|l|l|l|l|l|}
\hline & $\beta$ & Standard Error of $\beta$ & $\mathrm{t}$ & $\mathrm{P}$ & $\mathrm{R}^{2}$ \\
\hline PU & 0.404 & 0.133 & 3.092 & $<0.01$ & 0.108 \\
\hline
\end{tabular}

As appears in Table 5, the test of Hypothesis 3 (H3) shows that Perceived Ease of Use (PEOU) has a significant influence on Attitude $(A T)(P<0.01)$. Thus, PEOU significantly influences Attitude of instructors (AT).

Table 5: Regression results for $\mathrm{H3}$

\begin{tabular}{|l|l|l|l|l|l|}
\hline & $\beta$ & Standard Error of $\beta$ & $\mathrm{t}$ & $\mathrm{P}$ & $\mathrm{R}^{2}$ \\
\hline PEOU & 0.330 & 0.057 & 5.735 & $<0.01$ & 0.243 \\
\hline
\end{tabular}

Regarding Hypothesis 4 (H4), the regression analysis shows that perceived ease of use (PEOU) significantly influences perceived usefulness (PU) $(\mathrm{P}<0.01)$. The results presented in Table 6 indicate that PEOU significantly influences PU.

Table 6: Regression results for $\mathrm{H4}$

\begin{tabular}{|l|l|l|l|l|l|}
\hline & $\beta$ & Standard Error of $\beta$ & $\mathrm{t}$ & $\mathrm{P}$ & $\mathrm{R}^{2}$ \\
\hline PEOU & 0.340 & 0.058 & 5.742 & $<0.01$ & 0.235 \\
\hline
\end{tabular}

Finally, hypothesis 5 (H5) is deemed to be not supported. As Table 8 shows, attitude (AT) has no significant impact on $\mathrm{BI}(\mathrm{P}>0.01)$. 
Table 7: Regression results for $\mathrm{H4}$

\begin{tabular}{|l|l|l|l|l|l|}
\hline & $\beta$ & Standard Error of $\beta$ & $\mathrm{t}$ & $\mathrm{P}$ & $\mathrm{R}^{2}$ \\
\hline PEOU & 0.0 .325 & 0.058 & 6.064 & $<0.01$ & 0.235 \\
\hline
\end{tabular}

Table 8summarizes the results obtained from testing the research hypotheses. The results confirmed that there was a statistical correlation between the predicted directions of the research model. Overall, three of hypotheses were supported by the collected data.

Table 8: Summary of the Hypothesis Testing

\begin{tabular}{|c|l|c|c|c|}
\hline Hypotheses & Path & Path coefficient & $t$-value & Results \\
\hline H1 & PU $\rightarrow$ BI & 0.265 & 2.234 & Supported $(\mathrm{P}<0.01)$ \\
\hline H2 & PUAT & 0.504 & 4.092 & Supported $(\mathrm{P}<0.01)$ \\
\hline H3 & PEOUA & 0.330 & 5.735 & Supported $(\mathrm{P}<0.01)$ \\
\hline H4 & PEOU $\rightarrow$ PU & 0.340 & 5.742 & Supported $(\mathrm{P}<0.01)$ \\
\hline H5 & AT $\rightarrow$ BI & 0.325 & 6.064 & $\begin{array}{c}\text { Not Supported } \\
(\mathrm{P}<0.01)\end{array}$ \\
\hline
\end{tabular}

\section{CONCLUSION}

In light of the global trend towards e-learning, the higher education institutions in Jordan have witnessed radical changes in the way they operate (Alshboul, 2011). However, the adoption of elearning has resulted in several challenges, more particularly users acceptance. The current study using the technology acceptance model (TAM) aimed to predict the acceptance of elearning by Jordanian students. The findings have clearly revealed several useful implications. As in similar studies (Cheung, Lee \& Chen, 2005; Saadeet al., 2007), this work indicated that TAM can be employed as a useful theoretical base to predict and understand users' intentions to use e-learning. It also confirmed that in order to motivate students' intentions to use technology in their learning environment, it is essential to present a positive perception of technology usefulness - particularly as students' attitude may not associate this element with being at a similar level of importance.

From a managerial perspective, e-learning training and improvement helped to focus on how technology could help instructors to develop their performance and effectiveness in learning, rather than on the actual usage of technology. Moreover, while the results demonstrated that perceived usefulness had no significant influence on instructor's attitude, perceived ease of use significantly influenced both attitude and perceived usefulness. Therefore, learning technologists and educational developers should guarantee that e-learning interfaces are userfriendly through regular user engagement during development. Outcomes recommend that this will encourage instructors to more readily identify the benefits of e-learning and explore the opportunities it offers them to improve their performance. Consequently, this will encourage greater participation in elearning with a positive and creative attitude.

Future studies could be conducted to examine TAM with a different sample of instructors and a wider range of information technology applications. This could involve testing TAM by including the technology actual usage construct in the research model, which could enhance the predictable levels of information technology acceptance by instructors. Finally, the TAM model could be expanded to include additional beliefs that could impact e-learning acceptance such as social influence. Additionally, TAM could be modified by adding antecedents of both perceived ease of use and perceived usefulness. These antecedents should be exclusive to the e-learning.

\section{ACKNOWLEDGMENT}

The authors are grateful to the Middle East University, Amman, Jordan for the full financial support granted to cover the publication fee of this research article. 


\section{References}

Abbad, M.M. , Morris, D. , Al-Ayyoub, A. and Abbad, J.M. (2010) Students' decisions to use an eLearning system: a structural equation modelling analysis. International Journal of Emerging Technologies in Learning, volume 4 (4): 4-13

Adewole-Odeshi, E. (2014). Attitude of Students Towards E-learning in South-West Nigerian Universities: An Application of Technology Acceptance Model, Library Philosophy and Practice (e-journal).

Ajzen, I. (2005). Attitudes, personality and behaviour(2nd ed.). Maidenhead: Open University Press.

Ajzen, I. (2012). Theory of planned behavior. Retrieved June 14, 2012 from

http://people.umass.edu/aizen/index.html

Ajzen, I., \&Fishbein, M. (1980).Understanding attitudes and predicting social behaviour. Englewood Cliffs, New Jersey: Printice-Hall.

Al-adwan, A. \&Smedley, J. (2013) 'Implementing e-Learning in the Jordanian Higher Education System : Factors affecting impact', International Journal ofEducation and Development using Information and Communication Technology (IJEDICT), 8 (1), pp. 121-135.

Alatawi, F.M.H, Dwivedi, Y.K, Williams, M.D and Rana, N.P., 2014. Exploring technological factors influencing knowledge management systems adoption in Saudi Arabian public sector: A validation of extended TAM model. IGov Workshop, 12-13 June 2013, Brunel University, London, pp. 82-97

Al-Gahtani, S. S. (2014). Empirical investigation of e-learning acceptance and assimilation: A structural equation model. Applied Computing andInformatics, 11(3), 158-169.

Ali Alamin, H., \&Elgabar E. (2014). Success Factors for Adopting E-learning Application in Sudan. International Journal of Soft Computing and Engineering (IJSCE), 3(6).

Almarabeh T.( 2014). Students' Perceptions of ELearning at the University of Jordan, International Journal of Emerging Technologies in Learning (IJET), Volume 9 No 3.

Al-Mobaideen,H. , Allahawiah,S , \&Alkhawaldeh, A. (2013). Factors influencing the effectiveness of elearning systems in the educational process("electronic learning system") (eduwave): Jordan case study. European ScientificJournal, volume 8.

Al-Shboul, M. (2013). The level of e-Learning integration at The University of Jordan: Challenges and opportunities. International Education Studies, 6(4), 93-113.

Altarawneh, H. (2011). A Survey of E-Learning Implementation Best Practices inJordanian Government Universities. IJAC-4(2).

Altarawneh, M. (2013). Factors Affecting the Adoption of E-Learning: Jordanian Universities Case Study. Computer Engineering and Intelligent Systems . 4(3)

Arbaugh, J. (2002). Managing the on-line classroom: A study of technological and behavioural characteristics of web-based MBA courses. The Journal of High Technology Management Research, 13 (2), 203-223. DOI: 10.1016/S1047-8310(02)00049-4.

Chang, C., Yan, C \& Tseng, J. (2012).“Perceived convenience in an extended technology acceptance model: Mobile technology and English learning for college students”. Australasian Journal of Educational Technology, 28 (5), pp. 809-826.

Chen, S., Li, S \& Li, C. (2011). "Recent Related Research in Technology Acceptance Model: Aliterature Review”. Australian Journal of Business and Management Research, 1 (9),pp.124-127.

Davis, F. D. (1993). User acceptance of information technology: System characteristics, user perceptions and behavioral impacts. Internation Journal of Man-Machine Studies, 38(3), pp. 475-87.

Davis. F. (1989).Perceived Usefulness, Perceived Ease of Use and user acceptance of information technology. MIS Quaterly, 319-340. Retreived 13 Feburary, 2010 from: http://www.jstor.org/stable/249008.

Ducey,A. (2013). Predicting tablet computer use: An extended technology acceptance model. Master Thesis, University of South Florida, University of South Florida. United States of America.

Dulcic, Z., Pavlic, D. \&Silic, I. (2012).Evaluating the intended use of decision support system (DSS) by applying technology acceptance model (TAM) in business organizations in Croatia. Social and Behavioral Sciences, 58, pp. 1565-1575 
Khasawneh, M. (2015). Factors Influence e-Learning Utilization in Jordanian Universities Academic Staff Perspectives. 4th International Conference on Leadership, Technology, Innovation and Business Management.

Kruglanski, A., \&Stroebe, W. (2005). The influence of beliefs and goals on attitudes: Isues of structure, function and dynamics. In D. Albarracín, B. Johnson, \& M. Zanna, (Eds.), The handbook of attitudes (pp. 323-368). London: Lawrence Erlbaum Associates.

Lee, Y., Hsieh, Y. \& Hsu. (2011). "Adding Innovation Diffusion Theory to Technology Acceptance Model: Supporting Employees' Intentions to use E-learning Systems”. Educational Technology \& Society, 14 (4), pp. 124-137.

Lee, Y.-K.(2001). Factors affecting learner behavioural intentions to adopt webbased learning technology in adult and higher education.Unpublished doctoral dissertation, University of South Dakota

Masrom, M. (2007).Technology Acceptance Model and e-learning.The 12thInternational Conference on Education.Sultan HassanalBolkiah Institute ofEducation, Universiti Brunei Darussalam. Retrieved 13 February, 2010 from: http://eprints.utm.my/5482/1/MaslinMasrom2006 Techn.pdf

McGill, T.J., Klobas, J.E., \&Renzi, S. (2014). Critical success factors for the continuing of elearning initiatives. The Internet and Higher Education, 22, 24-36.

Moolla, A. \&Bisschoff, C. (2012)."Validating a Model to Measure the Brand Loyalty of Fast Moving Consumer Goods".J. SocSci, 31 (2), pp.101-115.

Muheisin,I. (2010). The role of e-learning systems in addressing the problems of education in Arabic.European Scientific Journal, volume 10.

Ngai, E., Poon, J., \& Chan, Y. (2007). Empirical examination of the adoption of WebCT using TAM. Computers \& Education, 48 (2), 250-267.

Nisperos, L. S. (2014). Assessing the E-Learning Readiness of Selected Sudanese Universities. Asian Journal of Management Sciences \& Education Vol. 3(4) October 2014.

Nunnally, J. (1978). Psychometric Theory.New York: McGraw-Hill.

Park, S. Y. (2009). An Analysis of the Technology Acceptance Model in Understanding University Students' Behavioral Intention to Use e-Learning. Educational Technology \& Society, 12 (3), 150-162.

Pituch, K., \& Lee, Y.-K. (2006). The influence of system characteristics on elearning use. Computers \& Education, $47,222-244$.

Qteishat, M., Alshibly, H., Alqatawna, H, \& Al-Ma'aitah, M. (2013). Factors Influencing the Adoption of E-Learning in Jordan:an Extended TAM Model.European Journal of Business and Management, volume 5.

Rosenberg, M., \&Hovland, C. (1960).Cognitive, affective and behavioural components of attitudes.In C. Hovland, \& M. Rosenberg, Attitude organisation and change (pp. 1-14). New Haven, CT.: Yale University Press.

Sek, Y., Lau, S., Teoh, K. \& Law, C. (2010). "Prediction of User Acceptance and Adoption of Smart Phone for Learning with Technology Acceptance Model”. Journal of Applied Sciences, 10 (20), pp. 2395-2402.

Sekaran, U. (2010). Research methods for business: A skill building approach. New York, NY,Wiley-India.

Suki, N.M. \&Suki, N.M. (2011). Exploring the relationship between perceived usefulness, perceived ease of use, perceived enjoyment, attitude and subscribers' intention towards using $3 \mathrm{G}$ mobile services. Journal of Information Technology Management, 22(1), pp. 1-7.

Teo, T. (2009).Evaluating the Intention to Use Technology among Student Teachers: A Structural Equation Modeling Approach.International Journal of Technology in Teaching and Learning, 5 (2), pp.106-118.

Teo, T., Luan, W. \& Sing, C. (2008). A cross-cultural examination of the intention to use technology between Singaporean and Malaysian pre-service teachers: An application of the technology acceptance model. Educational Technology and Society, 11(4), pp. 265- 284. 